\title{
Insights from Testing a Modified Dynamic Adaptive Policy Pathways Approach for Spatial Planning at the Municipal Level
}

\author{
Christoffer Carstens ${ }^{1,2, * \mathbb{C}}$, Karin Mossberg Sonnek ${ }^{3}$, Riitta Räty ${ }^{3}$, Per Wikman-Svahn ${ }^{4}(\mathbb{D}$, \\ Annika Carlsson-Kanyama ${ }^{2}$ and Jonathan Metzger ${ }^{5}$ \\ 1 County Administrative Board of Gävleborg, 80266 Gävle, Sweden, Royal Institute of Technology, \\ 10044 Stockholm, Sweden \\ 2 Department of Sustainable Development, Environmental Science and Engineering, \\ KTH Royal Institute of Technology, 10044 Stockholm, Sweden; annikack@kth.se \\ 3 Defence Analysis, Swedish Defence Research Agency, 16490 Stockholm, Sweden; \\ karin.mossberg@foi.se (K.M.S.); riitta.raty@foi.se (R.R.) \\ 4 Department of Philosophy and History, KTH Royal Institute of Technology, 10044 Stockholm, Sweden; \\ perwi@kth.se \\ 5 Division of Urban and Regional Studies, KTH Royal Institute of Technology, 10044 Stockholm, Sweden; \\ jonathan.metzger@abe.kth.se \\ * Correspondence: christoffer.carstens@lansstyrelsen.se; Tel.: +46-10-225-1355
}

Received: 30 November 2018; Accepted: 8 January 2019; Published: 15 January 2019

\begin{abstract}
The Dynamic Adaptive Policy Pathways (DAPP) approach has successfully been used to manage uncertainties in large infrastructure projects. However, the viability of the DAPP approach for spatial planning in smaller municipal settings is not clear. This paper examines opportunities and constraints of using adaptive pathways approaches to help small municipalities plan for future sea-level rise. The methodology was based on developing a simplified DAPP-approach, which was tested in a multiple experimental case study of spatial planning projects in three municipalities in Sweden. The results show that the approach promoted vulnerability-based thinking among the end-users and generated new ideas on how to manage the uncertain long-term impacts of future sea-level rise. However, the increased understanding of uncertainties was used to justify static, rather than adaptive, solutions. This somewhat surprising outcome can be explained by perceived legal constraints, lack of experience of adaptive pathways, and unwillingness to prescribe actions that could prove difficult to enforce in the future. More research is needed to further understand at what planning phases dynamic policy pathway approaches work best and how current barriers in legislation, practices, mind-set, organization, and resources can be overcome.
\end{abstract}

Keywords: pathways; adaptation; uncertainty; sea-level rise

\section{Introduction}

Coastal cities around the world are increasingly becoming aware of the need to adapt and plan for rising sea levels over the foreseeable future. However, the severe uncertainties in both the speed and magnitude of future sea-level rise present a challenge to normal approaches to spatial planning and creates risks of maladaptation [1]. Potential threats from sea-level rise can also be a new and complicated issue to decision makers. When faced with such decisions under 'deep uncertainty', it is commonly suggested that adaptive plans, which allow for changing pathways as the future unfolds, can provide guidance for better decision making [2-4]. Adaptive pathways thinking has been used for managing water-related uncertainties in large infrastructure projects [5], such as the 
Dutch Delta Program [6], coastal adaptation in New York City [7], the Thames Estuary 2100 project [8], and river basin management [9]. Pathway approaches have also been previously applied in local settings [10-14]. Other studies have been purely hypothetical, illustrating the possibilities of adaptation pathways $[15,16]$.

Dynamic Adaptive Policy Pathways (DAPP) is a decision-support method developed out of the methods "Adaptive Policymaking" and "Adaptation Pathways" [17]. DAPP is based on planning beforehand under which circumstances an option might fail, identifying actions that can be triggered later, and visualizes sequences of actions over time in an "adaptation pathways map". DAPP has more recently been used as a basis for further development in a method called Collaborative Risk Informed Decision Analysis (CRIDA), which is a comprehensive decision-support method for water resources management [18]. DAPP and CRIDA are, thus, two state-of-the-art decision-support approaches for creating adaptive pathways. However, the full application of these methods would require a significant effort from both process leaders and participants in terms of knowledge, time, and data processing.

Adaptive pathways approaches, such as DAPP and CRIDA, have great potential for improving planning under deep uncertainty, but they can be perceived as complex, difficult, and resource-demanding. This may be less of a problem for mega-projects, such as the Thames Estuary Project, however, for smaller projects, it becomes a major concern. It has previously been argued that there is a lack of studies that examine the efforts and resources required to implement adaptation pathways in practice [14], and it is not clear if the approaches are feasible within the current legal frameworks [19].

The main research question of the present study is as follows: How can a dynamic adaptive pathway approach be implemented in current spatial planning to manage uncertainties in future sea-level rise in small- to medium-sized municipalities in Sweden? The question raised should have a broader interest in relation to other contexts because spatial planning has a legal framework and practices that limit the feasibility of new methods in most countries [19]. The article can be seen as a contribution to the statement by Lin et al. [12] to the effect that little work has been done to evaluate the current use of adaptation pathways and their utility for practitioners and decision makers.

To examine the possibilities for using an adaptive pathways approach to help small municipalities to plan for future sea-level rise, the present study developed a simplified method, inspired by both DAPP and CRIDA. The resulting approach, which we call 'DAPP-light', consists of a format adapted to the municipal context and designed for application in three 6-h workshops.

The paper is structured as follows. In Section 2 the research design consisting of an experimental case study in three municipalities is described together with the DAPP-light approach that was developed. In Section 3 the results from testing the approach in the case studies are presented. Finally, Section 4 provides a concluding discussion focusing on the opportunities and constraints of the approach and broader insights.

\section{Materials and Methods}

\subsection{Spatial Planning and Adaptation to Climate Change in Sweden}

Spatial planning in Sweden is regulated in the Plan and Building Act [20], which stipulates that municipalities are responsible for spatial planning. The planning system consists of four different types of plans, as follows: the regional plan, municipal comprehensive plan, area regulations, and detailed development plan. Only two of these are legally binding documents (area regulations and detailed development plan). The county administrative boards are responsible for safeguarding and coordinating state interests during the plan development process. The county administrative boards should also safeguard national interests, environmental quality standards, inter-municipal interests, shoreline protection, and health and safety issues, specifically flooding, landslides, and erosion. In some counties, these requirements have led to specific county-wide recommendations on the lowest acceptable foundation level (expressed as altitude) for coastal development. This level 
varies between counties, but it generally consists of two parts; the first considers projected future water levels at high water, and the second accounts for uncertainties due to local effects and uncertain climate projections. In the county of Stockholm, these parts are $+180 \mathrm{~cm}$ and $+90 \mathrm{~cm}$, respectively, resulting in a recommendation of $+270 \mathrm{~cm}$ until the year 2100 [21].

Adaptation in Sweden has been a central component of climate policy since the final report from the Swedish Commission on Climate and Vulnerability [22]. After the report's release, climate adaptation has been conducted mainly at the regional level by the 21 county administrative boards with the objective of initiating, coordinating, and stimulating adaptation at the municipal level. The county administrative boards have relied on climate-impact data from different expert authorities, such as the Swedish Meteorological and Hydrological Institute, Swedish Geotechnical Institute, and Swedish Geological Survey. As a result, adaptation in Sweden at the regional level has been mainly top-down and driven by climate impact studies rather than vulnerability-based strategies. However, the new Swedish National Strategy for Climate Adaptation [23], adopted in March 2018, states that adaptation in Sweden should follow several guiding principles at all levels. These principles are as follows: sustainable development, mutuality regarding mitigation, the scientific basis precautionary principle, integration, flexibility, uncertainty management, risk management, flexible time horizon, and transparency. Several of these principles have not previously been part of mainstream adaptation in Sweden, and they will pose different challenges to Swedish actors at both the national and local levels. This is especially the case for the principles of flexibility, uncertainty management, risk management, and flexible time horizon. Together with the new National Strategy, an amendment to the national Plan and Building Act was established requiring municipalities to present their views on climate-related risks, especially regarding flooding and landslides, in their comprehensive plans. At present, it is not clear what implications this will have for adaptation practices at the regional and local levels, but it should be evident that methods for dealing with uncertainties and risk-based approaches will have to be adopted. In this study, we have tested introducing such a risk-based approach into spatial planning in Swedish municipalities.

\subsection{Research Design}

The research design was based on a multiple experimental case study [24]. Three cases were chosen on the replication logic that all cases should be challenged by sea-level rise but lacking strategic plans on how to cope with it. Another replication logic was that all cases should have plans or expectations for building houses at the seashore, mostly to attract residents with high incomes.

In each case, a planning process based on policy pathways was tested during three workshops. The process and its results were then described in a report and reviewed by the workshop participants, as seen in Figure 1. In all the municipalities, officials with relevant competences, for example, in planning, climate adaptation, sewage and water systems, and traffic planning formed a working group for each municipal workshop. The group sizes varied between five and eight persons. The workshops were facilitated by two to four researchers with experience in facilitating, modelling, and uncertainty management. The researchers documented the results during the workshops. 
Case 3

Case 2

\section{Case 1}
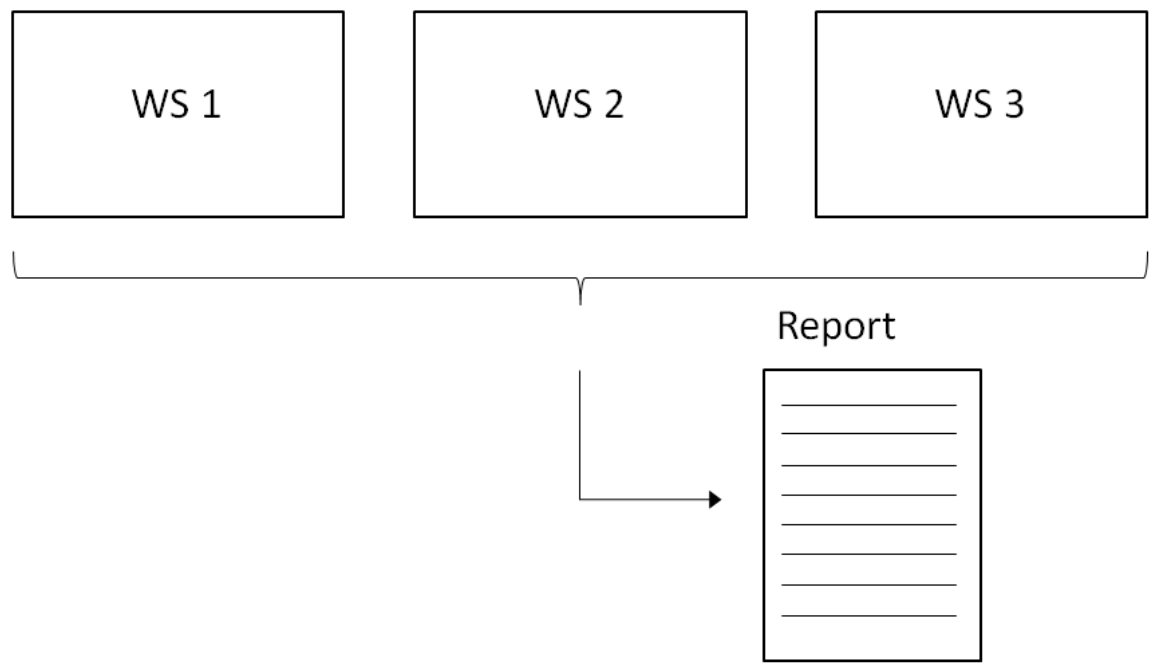

Figure 1. Research design. Each experimental case study was conducted during three workshops and documented in a report.

\subsection{The DAPP-Light Approach}

The DAPP-light approach developed for the purpose of this project was based on DAPP [17] and CRIDA [18]. The approach focussed on limited parts of the full DAPP and CRIDA methods, namely the following: (1) describing the current situation and decision context; (2) making a bottom-up vulnerability assessment; (3) identifying actions; and (4) developing adaptation pathways and finding robust strategies. DAPP and CRIDA also include steps for designing an adaptive plan, implementing the plan and monitoring important parameters for detecting early warning signals for when it is necessary to implement actions. These last steps were not included in our method due to the short duration of the cases (months rather than the decades that would be required in a real case). Instead, we had discussions about how these steps may be carried out in practice.

Due to the limited resources for the municipalities, we imposed a constraint that the methods should be able to be implemented over three 6-h workshops. The first workshop focussed on scoping the problem, identifying criteria for success and events that were to be avoided. The second workshop focussed on choosing levels of acceptable probabilities of flooding for the different events. The third workshop focussed on finding adaptive pathways that would avoid the undesirable events. The main steps in the three workshops are illustrated in Figure 2.

The first workshop started with a presentation of the research programme. After that, an introduction to the uncertainties of future sea-level rise was provided to give the participants an awareness of the sea-level rise in their regions and develop an understanding of the great uncertainties in future predictions. In addition, extreme water levels, recurrence intervals, probabilities, and the relations between these terms were discussed. Thereafter, we described the method to be used during the three workshops. 
The first step in the method aimed to have the group formulate and agree on the problem that should be discussed during the workshops, identical to the approaches in DAPP and CRIDA. We asked the participants to find an up-to-date and relevant planning problem in the municipality (e.g., 'How can we plan and create a resilient and attractive environment based on existing and new buildings in our municipality despite the flooding risks?'). We also asked them to specify the area to be analysed. Following this, we asked the group to formulate the criteria for success, a process that is central in many methods for robust decisions, including DAPP and CRIDA. These were deduced from the problem formulation and could be described as the long-term objectives for the area studied (examples of success criteria defined during the study were avoiding damages from flooding in buildings, securing availability to vulnerable people, and making the area attractive to residents and visitors). The participants first identified success criteria in subgroups. After that, the entire group discussed and prioritised the criteria and chose about five of them to continue working with. For these criteria, the group was asked to formulate what would happen if the criteria were not met, resulting in so-called undesired events. For example, in the case where the criterion for success was to avoid damages in buildings from flooding, the corresponding undesired event was that the buildings were damaged. This step differs from DAPP and CRIDA, and it was introduced for promoting the forthcoming discussion of risk during the second workshop.

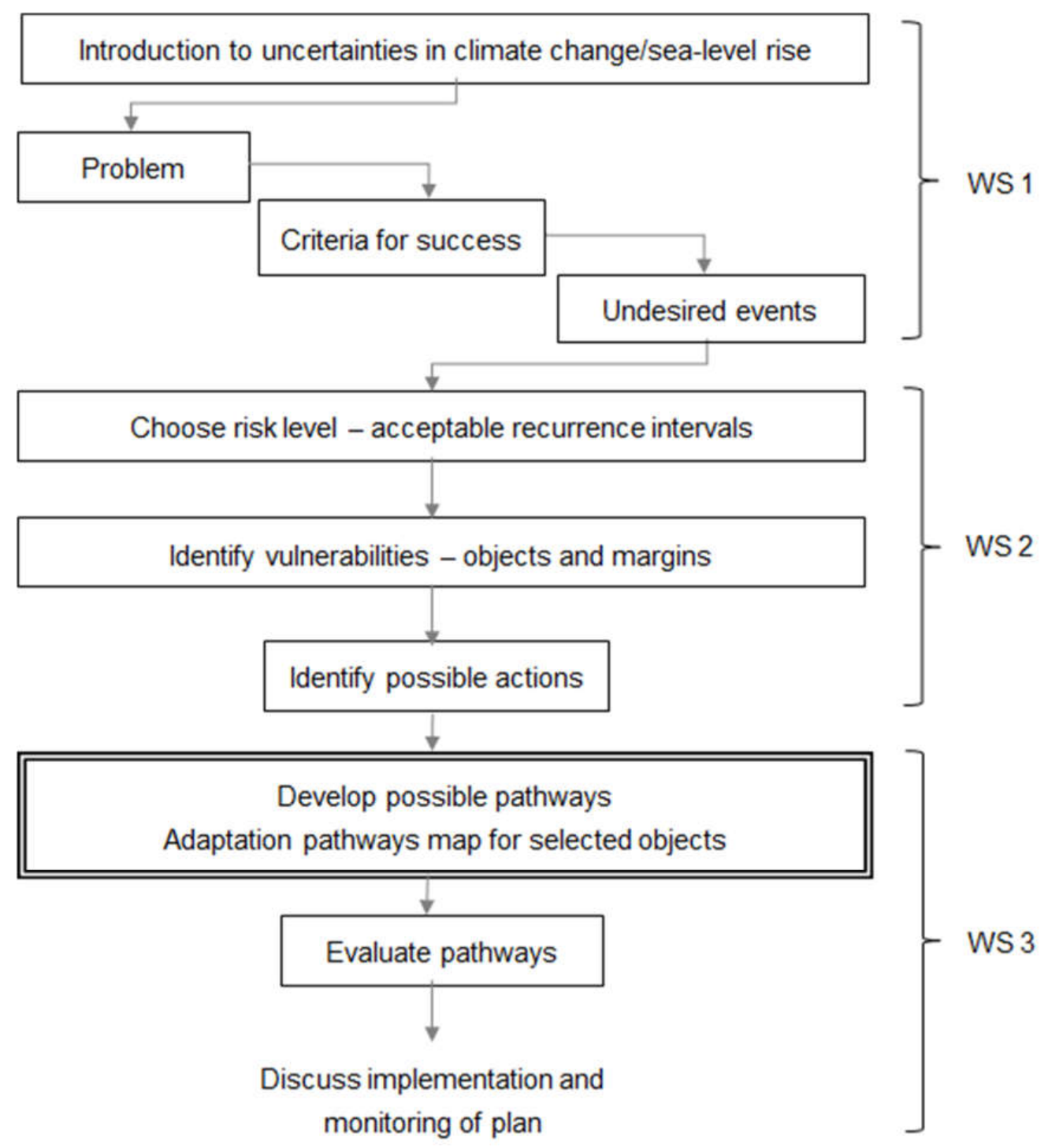

Figure 2. Structure and steps of the DAPP-light approach over three workshops (WS1, WS2, WS3). 
In the second workshop, the group chose risk levels, expressed as acceptable recurrence intervals for each undesired event they had identified in the first workshop. The participants had to choose recurrence intervals of 10,50,100, or 1000 years. A qualitative description of these recurrence intervals was given, such that 'a 100-year-event is rather rare, but most people will experience it once during a lifetime'. For each of the four given recurrence intervals, the corresponding sea levels were calculated. Thus, the acceptable risk level was based on present conditions and preferences, not regarding climate change.

Next, we had to be more specific rather than discussing the situation in general terms, so we asked the group to identify five to eight specific objects vulnerable to high water levels, for example, buildings, roads, or distribution stations. For each object, the position and altitude were documented. By comparing the altitude of the object with the water level at the chosen risk level, we obtained a measure of how much the sea level could rise (the safety margin) before the risk was higher than was acceptable. This step is a simplified version of the CRIDA stress test and the vulnerability analysis in DAPP. Following this, a discussion was encouraged in subgroups on what actions could be implemented to decrease the risk level and estimate to what sea level the actions would protect the object. We encouraged different sorts of actions, such as technical (e.g., barriers), informational (e.g., warnings), organisational (e.g., collaborations during crises), and planning instruments (e.g., requirements in building permits) [1].

Between the second and third workshops, the researchers prepared adaptation pathway maps $[2,17,19,25,26]$ in advance for the selected objects based on combinations of different actions suggested by the participants. The maps were visualised using the Dynamic Pathways Generator software [27] and presented at the beginning of the third workshop. Sea-level rise projections were chosen from the US Fourth National Climate Assessment [28] to provide a wide range of future sea-level rise scenarios and a perspective beyond the year 2100. Three scenarios were chosen, as follows: Int-low, Int, and High, giving a span of $0.5-2.0 \mathrm{~m}$ of global mean sea-level rise by 2100 . The participants were asked to choose one of the maps to develop further. They were also asked to discuss to what sea-level rise the chosen object should be protected (e.g., one group chose to protect their object, a built area that had been established, to a sea-level rise of $3 \mathrm{~m}$ ). In the discussion, new actions and combinations of actions were suggested. The different combinations of actions (pathways) were evaluated using a simplified scorecard [17] to assess the relative costs and describe the indirect effects and other consequences of each pathway. Finally, one pathway was chosen for further work.

In the final step, designing, implementing, and monitoring a plan were discussed with the participants. They suggested who could decide and implement the plan and how this could be done, as well as how such a plan would fit into the existing planning processes.

\subsection{Three Experimental Case Studies}

Based on the replication logics described above, we selected three municipalities located by the Baltic Sea-Danderyd, Gävle, and Söderhamn—which all have plans to build houses at the seashore. The locations of the three municipalities are shown in Figure 3. A short description of the municipalities and planning situations studied in the cases is given in Table 1. 


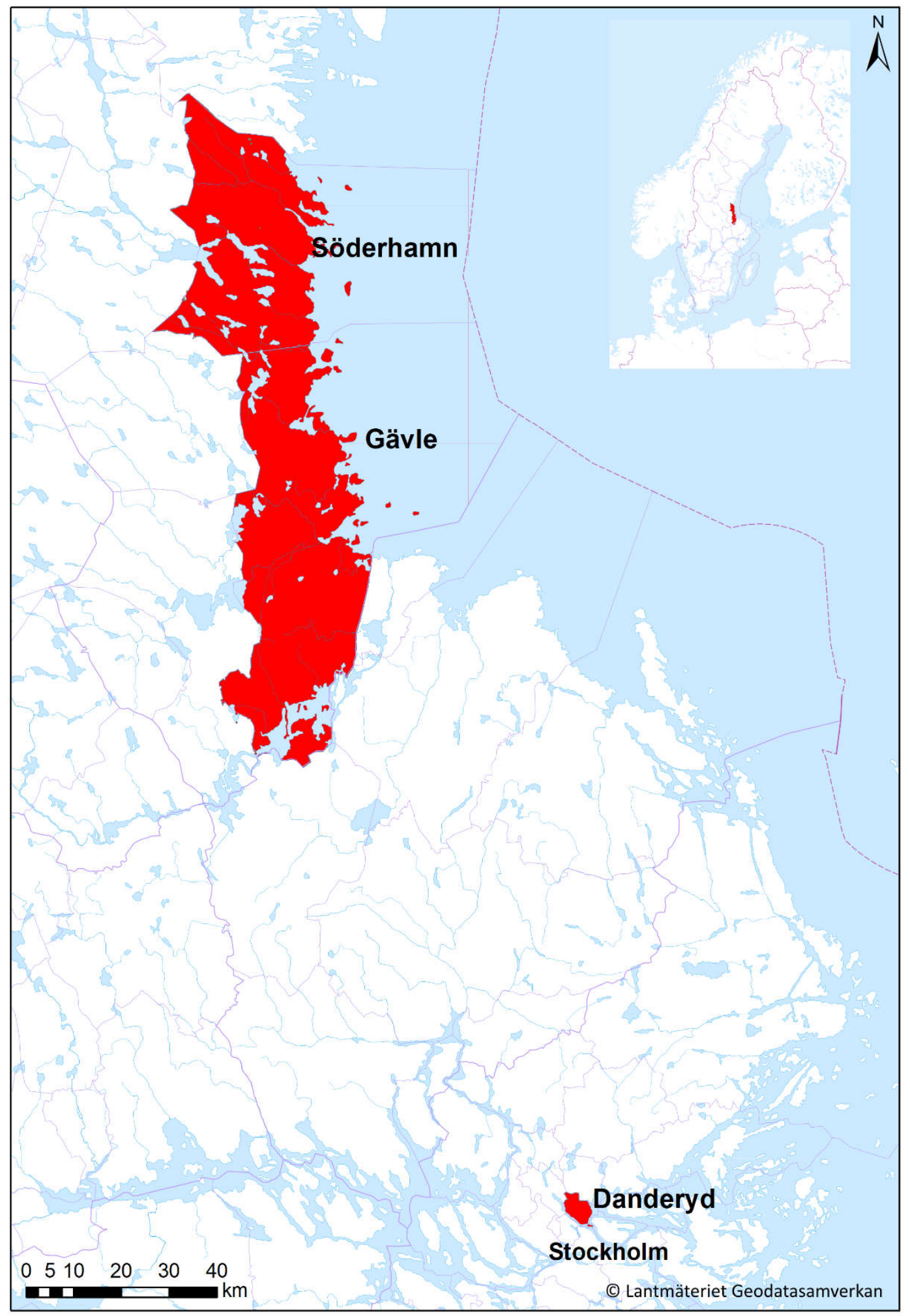

Figure 3. Danderyd, Gävle, and Söderhamn municipalities. 
Table 1. Description of the municipalities in which the case studies were performed—Danderyd, Gävle, and Söderhamn—and the planning process studied.

\begin{tabular}{|c|c|c|c|}
\hline & Danderyd & Gävle & Söderhamn \\
\hline Size [29] & 2640 ha & 161,384 ha & 106,085 ha \\
\hline $\begin{array}{l}\text { No. inhabitants } 2017 \\
(S C B, 2018)\end{array}$ & 32,888 & 100,603 & 25,782 \\
\hline $\begin{array}{l}\text { Isostatic land rise, per } \\
100 \text { years [30] }\end{array}$ & $0.65 \mathrm{~m}$ & $0.7 \mathrm{~m}$ & $0.75 \mathrm{~m}$ \\
\hline Spatial planning & $\begin{array}{l}\text { Current municipal } \\
\text { comprehensive plan was } \\
\text { approved in } 2006 \text { [31] }\end{array}$ & $\begin{array}{l}\text { Current municipal } \\
\text { comprehensive plan was } \\
\text { approved in } 2017 \text { [32] }\end{array}$ & $\begin{array}{l}\text { Current municipal } \\
\text { comprehensive plan was } \\
\text { approved in } 2006 \text { [33] }\end{array}$ \\
\hline $\begin{array}{l}\text { Planning process in } \\
\text { focus in the case studies }\end{array}$ & $\begin{array}{l}\text { Detailed plan }\left(0.02 \mathrm{~km}^{2}\right) \text {; the } \\
\text { municipality was considering } \\
\text { developing an area in one part } \\
\text { of the municipality }\end{array}$ & $\begin{array}{l}\text { Development site }\left(1 \mathrm{~km}^{2}\right) \text {; the } \\
\text { municipality was considering } \\
\text { several new developments to } \\
\text { transform parts of Gävle City }\end{array}$ & $\begin{array}{l}\text { Part of comprehensive plan } \\
\left(45 \mathrm{~km}^{2}\right) \text {; the municipality was } \\
\text { in the process of developing a } \\
\text { new comprehensive plan }\end{array}$ \\
\hline \multirow[b]{2}{*}{$\begin{array}{l}\text { Participants in the } \\
\text { workshops }\end{array}$} & & & Eight persons \\
\hline & \begin{tabular}{ll}
\multicolumn{2}{l}{ Five persons } \\
- & Environmental planner \\
1. & Spatial planner \\
2. & Water engineer \\
3. & Transport planner \\
4. & Chief gardener
\end{tabular} & \begin{tabular}{ll}
\multicolumn{2}{l}{ Six persons } \\
- & Two environmental \\
& spatial planners \\
1. & GIS engineer \\
2. & Water engineer \\
3. & Contingency officer \\
4. & Water coordinator
\end{tabular} & $\begin{array}{ll}\text { - } & \text { Municipal } \\
\text { 1. } & \text { planning strategist } \\
\text { 2. } & \text { Developmential planners } \\
\text { 3. } & \text { Road engineer } \\
\text { 4. } & \text { Two water engineers } \\
\text { 5. } & \text { Chief water officer }\end{array}$ \\
\hline
\end{tabular}

\section{Results}

The developed DAPP-light method was introduced and tested in the three municipalities. In the first workshop, the formulation of the problem to be studied was discussed by the participants. The problem was formulated differently by the three municipalities, as can be seen in Table 2 .

Table 2. Identified problems in the municipalities, formulated as questions.

\begin{tabular}{ccc}
\hline Danderyd & Gävle & Söderhamn \\
\hline $\begin{array}{c}\text { How can we plan for sustainable } \\
\text { and attractive environments } \\
\text { around the central Square of } \\
\text { Djursholm, despite the exposed } \\
\text { coastal location? }\end{array}$ & $\begin{array}{c}\text { How should the area be } \\
\text { developed for long-term, } \\
\text { sustainable, resilient development, } \\
\text { given the exposure to both fluvial } \\
\text { and coastal flooding? }\end{array}$ & $\begin{array}{c}\text { In what way is future sea-level rise } \\
\text { affecting the feasibility of the } \\
\text { comprehensive plan's strategies? }\end{array}$ \\
\hline
\end{tabular}

In the following, we exemplify the results from the case performed in Danderyd, but as mentioned above, all the cases were performed in the same way. During the first two workshops, criteria for success, undesired events, acceptable recurrence intervals, objects, margins, and actions were identified by the participants (in the process as described in Figure 2). To generate an overview of these steps and their interdependencies, we developed a tool in the form of a table (Table 3). This was filled in during the workshop processes, and the researchers added information about water levels for undesired events at today's sea level, the altitude of the chosen objects, and safety margins regarding sea-level rise. 
Table 3. An example of the table used to support and document the process. The examples originate from the case in Danderyd and cover the main concerns. The traffic-sign colouring of the safety margins marks the need for short-term actions.

\begin{tabular}{|c|c|c|c|c|c|c|c|}
\hline & \multicolumn{3}{|c|}{ General Attributes } & \multicolumn{4}{|c|}{ For specific objects } \\
\hline Criteria for Success & Undesired Events & $\begin{array}{c}\text { Acceptable } \\
\text { Recurrence } \\
\text { Interval of the } \\
\text { Undesired Event }\end{array}$ & $\begin{array}{l}\text { Corresponding } \\
\text { Water Level at } \\
\text { Present Climate }\end{array}$ & Description & Altitude & $\begin{array}{l}\text { Safety Margin (Highest } \\
\text { Sea-Level Rise That Meets } \\
\text { the Criteria of Acceptable } \\
\text { Recurrence Interval) }\end{array}$ & Possible Actions \\
\hline \multirow[t]{2}{*}{$\begin{array}{l}\text { Avoiding buildings } \\
\text { being flooded }\end{array}$} & \multirow[t]{2}{*}{$\begin{array}{l}\text { Basement, ground floor or } \\
\text { garage being flooded }\end{array}$} & \multirow[t]{2}{*}{100 years } & \multirow[t]{2}{*}{$+120 \mathrm{~cm}$} & $\begin{array}{l}\text { Basements near town } \\
\text { centre }\end{array}$ & $200 \mathrm{~cm}$ & $80 \mathrm{~cm}$ & $\begin{array}{l}\text { Make basements and garages } \\
\text { waterproof } \\
\text { Install non-return valves in } \\
\text { surface water system } \\
\text { Build a barrier along the sea witl } \\
\text { a height of }+350 \mathrm{~cm}\end{array}$ \\
\hline & & & & $\begin{array}{l}\text { New development at } \\
\text { former petrol station }\end{array}$ & $250 \mathrm{~cm}$ & $130 \mathrm{~cm}$ & $\begin{array}{l}\text { Do not allow basements in new } \\
\text { buildings } \\
\text { Raise the levels of the floors } \\
\text { (when needed) } \\
\text { Embank the new area }+200 \mathrm{~cm}\end{array}$ \\
\hline $\begin{array}{l}\text { Securing people's } \\
\text { access to home care } \\
\text { service }\end{array}$ & $\begin{array}{l}\text { Home care service does } \\
\text { not reach people when the } \\
\text { roads are flooded by more } \\
\text { than } 10 \mathrm{~cm}\end{array}$ & 10 years & $+95 \mathrm{~cm}$ & $\begin{array}{l}\text { Roundabout, the } \\
\text { lowest point of the } \\
\text { road between } x \text { and } y\end{array}$ & $300 \mathrm{~cm}$ & $205 \mathrm{~cm}$ & $\begin{array}{l}\text { Train personnel to be prepared } \\
\text { for flooding } \\
\text { Buy new vehicles that can } \\
\text { manage more water on the roads } \\
\text { Raise the street level }\end{array}$ \\
\hline $\begin{array}{l}\text { Securing access to } \\
\text { buildings for the } \\
\text { emergency service }\end{array}$ & $\begin{array}{l}\text { Emergency service cannot } \\
\text { reach all buildings when } \\
\text { the roads are flooded by } \\
\text { more than } 50 \mathrm{~cm}\end{array}$ & 1000 years & $+140 \mathrm{~cm}$ & Roundabout & $300 \mathrm{~cm}$ & $180 \mathrm{~cm}$ & $\begin{array}{l}\text { Adjust the ground levels in the } \\
\text { local plan } \\
\text { Buy new vehicles that can } \\
\text { manage more water on the roads } \\
\text { Raise the street level }\end{array}$ \\
\hline $\begin{array}{c}\text { Securing sewage } \\
\text { discharge }\end{array}$ & $\begin{array}{l}\text { The sewage discharge } \\
\text { points are flooded, } \\
\text { contaminating the } \\
\text { drinking water }\end{array}$ & 100 years & $+120 \mathrm{~cm}$ & Pumping station & $120 \mathrm{~cm}$ & $0 \mathrm{~cm}$ & $\begin{array}{l}\text { Make the pumping station } \\
\text { waterproof }\end{array}$ \\
\hline
\end{tabular}


Prior to the third workshop, we produced between three and five pathway maps for some of the identified objects in each municipality. In Danderyd, these objects were existing buildings, a pump station, existing important roads, a development plot under planning, and a park close to the shoreline. In each pathway map, the $x$-axis showed the rise of the sea level in meters $(0-5 \mathrm{~m})$. Underneath it, we displayed three different scenarios for sea-level rise until 2100 to give the participants an idea of the possible variations of future sea-level rise in this timeframe.

During the third workshop, the participants were asked to focus on one or two objects and refine the possible actions and timeframe in which they would be viable. We worked interactively with the Dynamic Pathway Generator [27] and asked the participants to define a number of pathways for each selected object. In Danderyd, the stakeholders focussed on actions to protect an area close to the sea where new housing is planned. They decided to include actions that would protect the area from up to $3 \mathrm{~m}$ of sea-level rise, although our sea-level rise scenarios showed that such levels would only happen after 2100, where many climate projections end. Still, the participants felt that a longer timeframe, up to 2150 , was needed when considering development projects. The final pathway map for this object is shown in Figure 4.

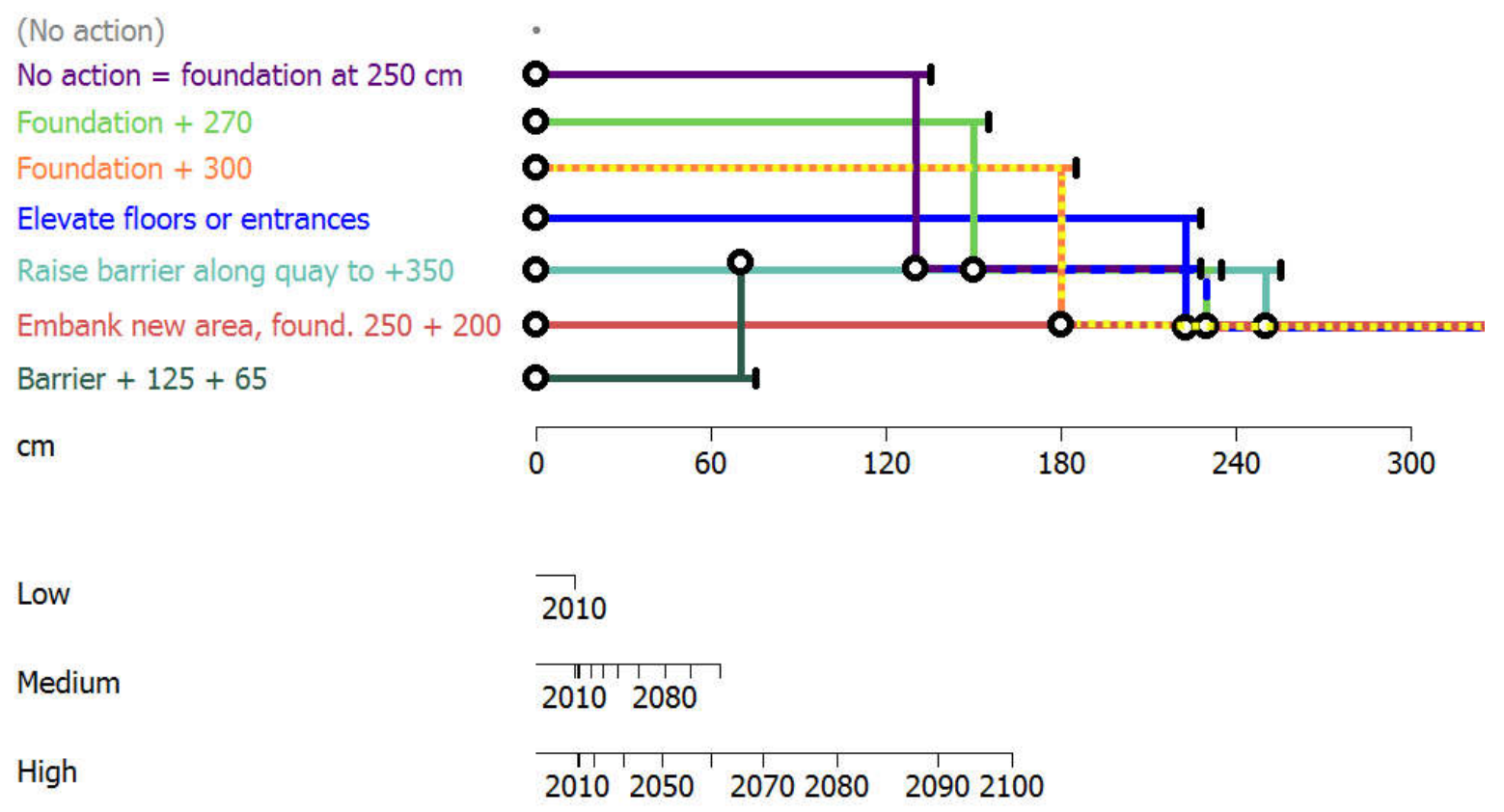

Map generated with Pathways Generator, (c)2015, Deltares, Carthago Consultancy

Figure 4. Example of the final pathway map for a specific housing project from Danderyd. The yellow-dotted line shows the selected pathway.

The processes and outcomes in the other two municipalities were similar, since they covered similar problems (urban developments at different scales). In each case study five pathway maps were produced and three to five pathways for one specific map were studied in depth.

During the third workshop, the pathways were also evaluated in terms of benefits and costs using a simplified method inspired by CRIDA. Here, the participants were asked to fill in a table where the different pathways were displayed along with questions about relative costs, goal fulfilment, and indirect benefits and drawbacks. After completing the table, the stakeholders evaluated the total results by picking out the most attractive pathway. In Danderyd, a pathway which included a 'foundation level' for new houses $3 \mathrm{~m}$ above the present sea level combined with an embankment of the area to protect the buildings was selected. The high ground level was supposed to protect the houses from up to $1.8 \mathrm{~m}$ of sea-level rise, and above that level, the embankment was the only option left. In the other two municipalities, the preferred pathways were based mainly on static adaptation actions. 


\section{Concluding Discussion}

One specific innovation of the method, described in the present paper, is a 'tool' in the form of a table, which we found useful and may be of interest for other developers of adaptive pathway approaches. Our impression is that filling out the table and working with the remaining stages in the process were performed with a reasonable effort from the participating professionals. The focus on tolerable risk levels at present conditions also initiated some interesting discussions and for many objects and criteria for success, the participants initially chose higher recurrence intervals than currents guidelines and recommendations. We also experienced keen interest in the process and outcomes from the participants, as the method was tested in real, ongoing planning cases. The opportunities and constraints for using the method further are discussed below, and they are generally based on the three workshop reports [34-36].

\subsection{Opportunities}

The method (including the tool, mentioned above) provides a simple yet clear and transparent overview of the vulnerabilities and risk-prone objects within the plan area. The focus on tolerable risk levels in the present climate provides a clear link between today's perceptions of risk and their future changes. The method is applicable to different planning situations, and it is relatively flexible in terms of what to include and to what level of detail. The tested method did provide a means for integrating robust decision support in municipal planning. In all three case studies, large uncertainties in future sea levels were incorporated into the decision making, through both high-end scenarios and adaptive pathways.

Based on feedback from the participants, we concluded that the method's capabilities to incorporate large uncertainties were appreciated, and a general comment was that the participants left the workshop series more confident about dealing with these uncertainties and with the knowledge that they are manageable. This was also stressed by several participants in the discussions during work-shop three.

One of the main opportunities, highlighted in all three case studies, was that the method facilitates cross-professional interactions. In small municipalities, there is rarely time to work collaboratively across units and professions, and the method provides a framework and reason for doing so in a structured way. This result is not specific for the tested method but, instead, it applies to most collaborative methods.

Participants in all three case studies indicated that the work provided some crucial insights into the climate-related uncertainties that were not known prior to the workshops. Another interesting result, strengthening the argument that the method did initiate creative processes and cross-fertilisation between professions, was that all the groups developed actions and pathways relevant to real problems that they were not aware of before the workshops. The workshops also raised the knowledge of possible methods for dealing with these uncertainties among the participants.

\subsection{Constraints}

The method required a high amount of effort and engagement from the participating municipalities, as well as the workshop leaders (researchers). As has been highlighted, for example, by Lawrence and Haasnoot [14], the uptake and implementation of DAPP (and CRIDA) can require a process that spans several years and includes a high number of participants and experts. One major obstacle is the participation of many professionals in the workshops. As noted above, this is also seen as one of the major benefits of the method, although it complicates the feasibility of implementation. It is simply difficult in current practices to gather a high number of officials for a number of consecutive workshops. This proved to be a potential obstacle in our simplified 'light' method, and for full-scale implementation of DAPP, CRIDA, and similar methods, the implications would be even larger. Several participants in all of the municipalities argued that it would be difficult to implement the methodology 
in everyday planning due to economic constraints, human resource limitations and the absence of methodological knowledge.

At present, the method also requires a certain amount of expertise in the field of the studied impacts, in this case, the risks from flooding caused by extreme sea levels. For a small- to medium-sized municipality, this is often lacking. This expertise could be purchased, but at a cost, and this is usually not feasible within the budget constraints of regular planning projects. Here, regional authorities (in Sweden, the County Administrative Boards) could be crucial partners and provide support. However, the experience and expertise for treating uncertainties in climate data vary in those organisations as well. Another issue relates to at what strategic level in the decision-making process it is appropriate to introduce the method. The comprehensive plan could be that level, but not all participants agreed with this notion. There is a risk when using the method at a too strategic level that the criteria for success and actions could also become too strategic, thereby potentially hampering innovative ideas, since the undesired events are generally extremely detailed. This discrepancy was highlighted in all the case studies.

It was difficult to formulate objectives in terms of main goals and criteria for success that were specific enough to provide a basis for safety margins, and at the same time, general enough to be relevant to all the participants. Earlier research $[37,38]$ has suggested that DAPP approaches have limitations originating from the fact that they are developed for large-scale infrastructure projects, where goals are usually few and uncontested, decision makers are known and identified, and objects are relatively few.

The feasibility of the DAPP concept in regular municipal planning was also an obstacle. As Wise et al. [37] discussed, adaptation is not separable from the surrounding context in which it occurs, and several other legal and sectorial constraints can be important for the feasibility of DAPP methods. Our study identified some specific obstacles concerning this-one jurisdictional and one more related to social and knowledge-based practices in the planning community-and a complicating factor for recommendations. As for the legal obstacle, according to the Planning and Building Act, spatial planning can regulate a certain number of things, each explicitly stated in the Act. Within a detailed development plan, the municipality may regulate things like land use, the extent and use of buildings, protective actions and so on. However, the regulations are supposed to be fixed to provide a transparent process and equal opportunities for developers, once the plan is decided upon. There is little to no room for prescribing adaptive solutions within the plan. This has been noted, for example, by Lawrence et al. [19], who stated that current planning frameworks are designed to promote static and time-bound planning and legal instruments. In the current framework, the only identified possibility is reserving land for future installations and facilities that could be used for eventual future flood protection that is not needed at the current levels. Another obstacle was more related to the participants' willingness to use adaptive methods in general. The participants found it difficult to relate to and use dynamic, adaptive solutions, since there are no possibilities for enforcing future actions in the plans and, therefore, they showed a preference for static solutions. It is also interesting to note that, in the cases where regional or local recommendations for the lowest foundation levels were present, it was perceived as difficult to work around them. A recommendation works both upwards and downwards, prohibiting development below it but also ensures development above it. The participants argued that it would also require quite some effort to persuade decision makers to decide on developments with higher safety margins than the prescribed present recommendations.

The methodology was found to be relatively complex. In a development area, especially under the geographical reach of a comprehensive plan, there are numerous objects and related threats. Individual pathway maps therefore have to be produced for all of these, resulting in a large number different maps that are often unrelated to one another. These maps then have to be compared and weighted against each other in the decision-making process. For a larger plan with multiple stakeholders and ambiguous goals, the effort can quickly become exhausting. This has previously been noted by Bosomworth et al. [38], who stressed that the simplicity of the pathway approach is easily lost in the 
complexity of numerous different actions and safety margins, different drivers of these actions and the general system complexity of real-life planning situations.

We did not observe that the participants preferred to investigate and elaborate adaptive pathways. Almost to the contrary, the innovative solutions mentioned above were predominantly static, and if the uncertainty did alter the decisions in any case, it was to choose more conservative solutions. The future uncertainties were used not to explore the decision space but to motivate higher levels of static security. It is difficult to say whether this is a result of inexperience with adaptive methods, that is, the difficulty of imagining adaptive solutions, or the legal and practical constraints described above. Another factor could be that expert-solicited static safety margins is the standard approach to manage uncertainties related to sea level rise in spatial planning in Sweden [39].

The approach developed and tested in the experimental case studies proved beneficial for providing insights about the uncertainties, related to climate change in general and sea-level rise specifically among the participating professionals. It also provided an appreciated cross-disciplinary collaboration among the workshop participants. However, in relation to the assumed superiority of flexible solutions as a preferable outcome of this type of exercise, we also found perceived legal obstacles and conflicts with current practices and planning frameworks. Somewhat surprising to us, the preferred options of the end users in all three cases relied heavily on static rather than adaptive solutions. Adaptive solutions were mostly introduced in the higher end of sea-level rise scenarios.

Based on our results, we propose that more research and development is needed to (i) understand the legal constraints of using dynamic pathways, especially dynamic, flexible solutions, in spatial planning; (ii) give recommendations on the appropriate strategic level at which dynamic pathways should be used; and (iii) develop methods for promoting the creation of flexible pathways within current and future spatial planning practices. Some of these issues will be addressed in forthcoming research which will also include in-depth interviews with the participating stakeholders about their attitude towards handling uncertainties before and after the workshops. The method itself will also be refined in collaboration with stakeholders and other actors such as experienced consultants with the aim of simplifying some of its first steps. In particular, more research is needed to understand in which contexts dynamic policy pathway approaches work best and how existing barriers in legislation, practices, mind-set, organisation, and resources can best be overcome.

Author Contributions: C.C. produced the original draft. C.C., K.M.S., R.R., P.W.-S. and A.C.-K. contributed to conceptualization, investigation, methodology review and writing-review and editing. J.M. contributed to conceptualization and writing-review.

Funding: This research was funded by the Swedish Civil Contingency Agency [Myndigheten för Samhällsskydd och Beredskap], grant number [2015-3629].

Conflicts of Interest: The authors declare no conflict of interest.

\section{References}

1. Noble, I.R.; Huq, S.; Anokhin, Y.A.; Carmin, J.; Goudou, D.; Lansigan, F.P.; Osman-Elasha, B.; Villamizar, A. Adaptation needs and options. In Climate Change 2014: Impacts, Adaptation, and Vulnerability. Part A: Global and Sectoral Aspects. Contribution of Working Group II to the Fifth Assessment Report of the Intergovernmental Panel of Climate Change; Field, C.B., Barros, V.R., Dokken, D.J., Mach, K.J., Mastrandrea, M.D., Bilir, T.E., Chatterjee, M., Ebi, K.L., Estrada, Y.O., Genova, R.C., et al., Eds.; Cambridge University Press: Cambridge, UK, 2014; pp. 833-868.

2. Walker, W.E.; Haasnoot, M.; Kwakkel, J.H. Adapt or perish: A review of planning approaches for adaptation under deep uncertainty. Sustainability 2013, 5, 955-979. [CrossRef]

3. Maier, H.R.; Guillaume, J.H.; van Delden, H.; Ridell, G.A.; Haasnoot, M. An uncertain future, deep uncertainty, scenarios, robustness and adaptation: How do they fit together? Environ. Model. Softw. 2016, 81, 154-164. [CrossRef] 
4. Kwakkel, J.H.; Walker, W.E.; Haasnoot, M. Coping with the wickedness of public policy problems: Approaches for decision making under deep uncertainty. J. Water Resour. Plan. Manag. 2016, 142, 01816001. [CrossRef]

5. Jeuken, A.; Haasnoot, M.; Reeder, T.; Ward, P. Lessons learnt from adaptation planning in four deltas and coastal cities. J. Water Clim. Chang. 2014, 6, 711-728. [CrossRef]

6. Kwadijk, J.C.; Haasnoot, M.; Mulder, J.P.; Hoogvliet, M.M.; Jeuken, A.B.; van der Krogt, R.A.; van Oostrom, N.G.; Schelfhout, H.A.; van Velzen, E.H.; van Waveren, H. Using adaptation tipping points to prepare for climate change and sea level rise: A case study in the Netherlands. Wiley Interdiscip. Rev. Clim. Chang. 2010, 1, 729-740. [CrossRef]

7. Rosenzweig, C.; Solecki, W.D.; Blake, R.; Bowman, M.; Faris, C.; Gornitz, V.; Horton, R.; Jacob, K.; LeBlanc, A.; Leichenko, R.; et al. Developing coastal adaptation to climate change in the New York City infrastructure-shed: Process, approach, tools, and strategies. Clim. Chang. 2011, 106, 93-127. [CrossRef]

8. Ranger, N.; Reeder, T.; Lowe, J. Addressing 'deep' uncertainty over long-term climate in major infrastructure projects: Four innovations of the Thames Estuary 2100 Project. EURO J. Decis. Process. 2013, 1, $233-262$. [CrossRef]

9. Abel, N.; Wise, R.M.; Colloff, M.J.; Walker, B.H.; Butler, J.R.; Ryan, P.; Norman, C.; Langston, A.; Anderies, J.M.; Gorddard, R. Building resilient pathways to transformation when "no one is in charge" insights from Australia's Murray-Darling Basin. Ecol. Soc. 2014, 21. Available online: https://www.jstor.org/stable/ 26270401 (accessed on 30 November 2018).

10. Barnett, J.; Graham, S.; Mortreux, C.; Fincher, R.; Waters, E.; Hurlimann, A. A local coastal adaptation pathway. Nat. Clim. Chang. 2014, 4, 1103-1108. [CrossRef]

11. Murphy, D.J.; Yung, L.; Wyborn, C.; Williams, D.R. Rethinking climate change adaptation and place through a situated pathways framework: A case study from the Big Hole Valley, USA. Landsc. Urban Plan. 2017, 167, 441-450. [CrossRef]

12. Lin, B.B.; Capon, T.; Langston, A.; Taylor, B.; Wise, R.; Williams, R.; Lazarow, N. Adaptation pathways in coastal case studies: Lessons learned and future directions. Coast. Manag. 2017, 45, 384-405. [CrossRef]

13. Zandvoort, M.; Campos, I.S.; Vizinho, A.; Penha-Lopes, G.; Lorencová, E.K.; van der Brugge, R.; van der Vlist, M.J.; van den Brink, A.; Jeuken, A. Adaptation pathways in planning for uncertain climate change: Applications in Portugal, the Czech Republic and the Netherlands. Environ. Sci. Policy 2017, 78, 18-26. [CrossRef]

14. Lawrence, J.; Haasnoot, M. What it took to catalyse uptake of dynamic adaptive pathways planning to address climate change uncertainty. Environ. Sci. Policy 2017, 68, 47-57. [CrossRef]

15. Stephens, S.A.; Bell, G.R.; Lawrence, J. Applying principles of uncertainty within coastal hazard assessments to better support coastal adaptation. J. Mar. Sci. Eng. 2017, 5, 40. [CrossRef]

16. Ramm, T.D.; Watson, C.S.; White, C.J. Strategic adaptation pathway planning to manage sea-level rise and changing coastal flood risk. Environ. Sci. Policy 2018, 87, 92-101. [CrossRef]

17. Haasnoot, M.; Kwakkel, J.H.; Walker, W.E.; ter Maat, J. Dynamic adaptive policy pathways: A method for crafting robust decisions for a deeply uncertain world. Glob. Environ. Chang. 2013, 23, 485-498. [CrossRef]

18. Mendoza, G.; Jeuken, A.; Matthews, J.H.; Stakhiv, E.; Kucharski, J.; Gilroy, K. Climate Risk Informed Decision Analysis (CRIDA). UNESCO and ICIWaRM, 2018. Available online: http://unesdoc.unesco.org/images/ 0026/002658/265895e.pdf (accessed on 30 November 2018).

19. Lawrence, J.; Bell, R.; Blackett, P.; Stephens, S.; Allan, S. National guidance for adapting to coastal hazards and sea-level rise: Anticipating change, when and how to change pathway. Environ. Sci. Policy 2018, 82, 100-107. [CrossRef]

20. Boverket. Legislation, Planning and Building Act (2010:900); Boverket: Karlskrona, Sweden, 2010; Available online: https: / / www.boverket.se/globalassets/publikationer/dokument/2016/legislation.pdf (accessed on 30 November 2018). 
21. Länsstyrelsen Stockholm, Rekommendationer för Lägsta Grundläggningsnivå Längs Östersjökusten i Stockholms Län (in Swedish), (Recommendations for Lowest Level of Foundation Along the Baltic Sea Coast in the County of Stockholm), Länsstyrelsen Stockholms Län, 2015. Available online: https: / /www. lansstyrelsen.se/download/18.4771ab7716298ed82ba6ec4e/1526068443621/Fakta\%202015-14\%20L\%C3\% A4gsta\%20grundl\%C3\%A4ggningsniv\%C3\%A5\%201\%C3\%A4ngs\%20\%C3\%96stersj\%C3\%B6kusten.pdf (accessed on 30 November 2018).

22. Ministry of Environment and Energy; SOU 2007:60-Sweden Facing Climate Change-Threats and Opportunities. Swedish Government Official Reports: Stockholm, 2007. Available online: https: / /www. government.se/legal-documents/2007/12/sou-200760/ (accessed on 30 November 2018).

23. Regeringens Proposition 2017/18:163 Nationell Strategi för Klimatanpassning (in Swedish), (Government Bill 2017/18:163 National Strategy for Climate Adaptation) Stockholm, 2018. Available online: https:/ / www.regeringen.se/rattsliga-dokument/proposition/2018/03/prop.-201718163/ (accessed on 30 November 2018).

24. Yin, R.K. Case Study Research, 5th ed.; SAGE: London, UK, 2014.

25. Kwakkel, J.H.; Haasnoot, M.; Walker, W.E. Developing dynamic adaptive policy pathways: A computer-assisted approach for developing adaptive strategies for a deeply uncertain world. Clim. Chang. 2015, 132, 373-386. [CrossRef]

26. Haasnoot, M.; Middelkoop, H.; Offermans, A.; ven Beek, E.; van Deursen, W.P.A. Exploring pathways for sustainable water management in river deltas in a changing environment. Clim. Chang. 2012, 115, 795-819. [CrossRef]

27. Deltares and Carthago Consultancy. Dynamic Pathways Generator. Available online: https://publicwiki. deltares.nl/display/AP/Pathways+Generator (accessed on 25 November 2018).

28. Sweet, W.V.; Horton, R.; Kopp, R.E.; LeGrande, A.N.; Romanou, A.; Wuebbles, D.J.; Fahey, D.W.; Hibbard, K.A.; Dokken, D.J.; Stewart, B.C.; et al. Sea level rise. In Climate Science Special Report: Fourth National Climate Assessment, Volume I; Global Change Research Program: Washington, DC, USA, 2017; pp. 333-363.

29. SCB Statistics Sweden. Kommuner i Siffror. (Municipalities in Numbers) SCB, 2018. Available online: https:/ / www.scb.se/hitta-statistik/sverige-i-siffror/kommuner-i-siffror/ (accessed on 1 October 2018).

30. Lantmäteriet. Postglacial Land Uplift. Lantmäteriet, 2016. Available online: https://www.lantmateriet. se/en/maps-and-geographic-information/GPS-och-geodetisk-matning/Referenssystem/Landhojning/ (accessed on 25 November 2018).

31. Danderyds Kommun, Översiktsplan för Danderyds Kommun, (Comprehensive Plan for Danderyd), Danderyds Kommun, 2006. Available online: https://www.danderyd.se/Bygga-bo-och-miljo/ Planerochutveckling/Oversiktsplan/ (accessed on 25 November 2018).

32. Gävle Kommun, Översiktsplan Gävle Kommun år 2030, (Comprehensive Plan for Municipality of Gävle), Gävle, 2017. Available online: http://old.gavle.se/Bygga-bo-miljo/Kommunens-planarbete/ Oversiktplaner/Gavle-2030/ (accessed on 25 November 2018).

33. Söderhamns Kommun, Översiktsplan för Söderhamns Kommun, (Comprehensive Plan for Municipality of Söderhamn), Söderhamn, 2006. Available online: https://www.soderhamn.se/byggaboochmiljo/ samhallsplanering/gallandeoversiktsplan.4.9564f013cf90e1dbcf11.html (accessed on 25 November 2018).

34. Mossberg Sonnek, K.; Carlsson-Kanyama, A.; Carstens, C.; Wikman Svahn, P. Test av Robusta Beslutsstödsmetoder-Ny Bebyggelse vid Djursholms torg i Danderyds Kommun (in Swedish), (Test of Robust Decision-Support Methods-New Development in Danderyd); KTH: Stockholm, Sweden, 2017.

35. Carstens, C.; Carlsson-Kanyama, A.; Wikman-Svahn, P.; Räty, R.; Mossberg Sonnek, K. Test av Robusta Beslutsstödsmetoder-Ny Bebyggelse längs Gavleåns utlopp i Gävle Kommun Rapport 2018:12 (in Swedish), (Test of Robust Decision-Support Methods-New Development along the Outlet of Gavleån in Gävle); Länsstyrelsen Gävleborg: Gävle, Sweden, 2018.

36. Räty, R.; Carstens, C.; Carlsson-Kanyama, A.; Wikman-Svahn, P.; Mossberg Sonnek, K. Test av Robusta Beslutsstödmetoder-Påverkan av Havsnivåhöjning i "Söderhamnsfjärden" i Söderhamns Kommun (in Swedish), (Test of Robust Decision-Support Methods_Implications from Sea-Level Rise in "Söderhamnsfjärden" in Söderhamn); KTH: Stockholm, Sweden, 2018. 
37. Wise, R.M.; Fazey, I.; Stafford Smith, M.; Park, S.E.; Eakin, H.C.; Archer Van Garderen, E.R.M.; Campbell, B. Reconceptualising adaptation to climate change as part of pathways of change and response. Glob. Environ. Chang. 2014, 28, 325-336. [CrossRef]

38. Bosomworth, K.; Leith, P.; Harwood, A.; Wallis, P. What's the problem in adaptation pathways planning? The potential of a diagnostic problem-structuring approach. Environ. Sci. Policy 2017, 76, 23-28. [CrossRef]

39. Carlsson-Kanyama, A.; Wikman-Svahn, P.; Mossberg Sonnek, K. We want to know where the line is: Comparing current planning for future sea-level rise with three core principles of robust decision support approaches. J. Environ. Plan. Manag.. in press.

(C) 2019 by the authors. Licensee MDPI, Basel, Switzerland. This article is an open access article distributed under the terms and conditions of the Creative Commons Attribution (CC BY) license (http:/ / creativecommons.org/licenses/by/4.0/). 